\title{
EFFECTS OF COARSE AGGREGATE SHAPE AND TEXTURE ON ENGINEERING PROPERTIES OF ROLLER COMPACTED CONCRETE PREPARED FOR HIGH TRAFFIC ROUTES
}

\begin{abstract}
Alban Chidiebere Ogbonna, Department of civil engineering, WaziriUmaru Federal Polytechnic BirninKebbi, PMB 1034 BirninKebbi GPO, Kebbi State, Nigeria. e-mail: alban.ogbonna@yahoo.com
\end{abstract}

\begin{abstract}
Use of roller-compacted concrete in pavement construction is increasing. Roller compacted concrete is a zero-slump, highly compacted concrete that is placed by equipment similar to that used in asphalt pavement construction. This investigation was conducted to collect the state-of-the-art information on effects of coarse aggregate size and texture on the strength and workability of roller-compacted concrete (RCC) for pavement construction and maintenance. Concrete specimens containing cubical and rough coarse aggregate, irregular and rough coarse aggregate, angular and rough coarse aggregate, rounded/spherical and smooth coarse aggregate, and flaky/elongated and rough coarse aggregate were prepared at 1:3:3 concrete mix ratio and 0.4 water cement ratio. Laboratory testing of specimens derived from the concrete specimens showed excellent results for cubical and rough coarse aggregate, irregular and rough coarse aggregate, and angular and rough coarse aggregate. Specimens from the rounded/spherical and smooth coarse aggregate, and flaky/elongated and rough coarse aggregate performed poorly in laboratory. The study therefore recommends the use of cubical and rough coarse aggregate, and irregular and rough coarse aggregate in the production of roller-compacted concrete for pavement construction and maintenance.
\end{abstract}

Keywords: Coarse aggregate size, Cubical coarse aggregate, Flaky coarse aggregate, Irregular coarse aggregate, Concrete pavement, Roller compacted concrete.

\section{INTRODUCTION}

Aggregates shape and size has a strong influence on properties of concrete. Rough surface textured particles increase the compressive strength of concrete up to $20-30 \%$ [36-38]. Rough surfaces have pores which have ability to form bond or create resistance against the applied load. The shape of aggregate is an important characteristic since it affects the workability of concrete. It is difficult 


\author{
Alban Chidiebere Ogbonna \\ Effects of coarse aggregate shape and texture on engineering properties of roller compacted concrete prepared \\ for high traffic routes
}

to really measure the shape of irregular body like concrete aggregate which are derived from different rocks. Not only will the characteristics of the parent rock but also the type of crusher used will influence the shape of aggregates [34-38]. The shape of the aggregate is very much influenced by the type of crusher and the reduction ratio i.e. the ratio of the size of material fed into crusher to the size of the finished product [32].

From the standpoint of economy in cement requirement for given water cement ratio, rounded aggregates are preferable to angular aggregates. On the other hand, the additional cement required for angular aggregates is offset to some extent by the higher strengths and sometimes by the greater durability as a result of the interlocking texture of the hardened concrete and higher bond characteristics between aggregate and cement paste [32-38].

Surface texture is an aggregate property, a measure of which depends upon the relative degree to which particle surfaces are polished or dull, smooth or rough. Surface texture depends on hardness, grain size, pore structure, structure of the rock and the degree to which forces acting on the particle surface have smoothed or roughened it. Hard, dense, fine - grained materials will generally have smooth fracture surfaces. Experience and laboratory experiments have shown that the adhesion between cement paste and aggregates is influenced by several complex factors in addition to the physical and mechanical properties of aggregates [29-33]. As surface smoothness increases, contact area decreases, hence a highly polished particle will have less bonding area with the matrix than a rough particle of the same volume [32].

The American Concrete Institute (ACI) 116R1 [6] defines RCC as "concrete compacted by roller compaction; concrete that, in its unhardened state, will support a roller while being compacted." Properties of hardened RCC can be similar to those of conventionally placed concrete. However, RCC can also be made with hardened properties that are outside the range of typical properties of conventionally placed concrete. The term "roller compaction" is also defined by ACI as "a process for compacting concrete using a roller, often a vibrating roller." The terms "rollcrete" and "rolled concrete" are no longer to be used.

Roller-compacted concrete (RCC) as a paved surface offers facility owners and pavement designers a concrete pavement alternative that may better meet the requirements of specific pavement projects than conventionally cast-in-place concrete pavements. RCC pavement applications can be tailored to the specific needs of a project, particularly those associated with roadway projects within the residential, commercial, and urban roadway sectors. RCC pavement has been used in the following applications $[7,8,10,25,26]$. 
An important benefit of RCC is its cost-effectiveness and ease of construction. RCC pavement essentially mirrors a conventional Portland cement concrete (PCC) pavement in terms of joint spacing and design thickness. However, RCC is engineered and constructed differently than conventional concrete, involving different placement and design considerations even though the concrete mixture is made of the same constituent materials. Some of the differences include the following $[7,8,10,25]$.

The primary benefit of RCC is that it can be constructed more quickly and cost-effectively than conventional concrete and multiple-lift asphalt pavements. Construction cost histories of RCC and conventional concrete show that the unit cost of RCC is often lower than an equivalent section of conventional concrete or asphalt pavement [39-40]. The specific percentage of savings usually depends on the complexity of placement and on the total amount of concrete placed. Savings associated with RCC over conventional concrete are primarily due to reduced cement content, reduced forming and placement costs, and reduced construction times. Moreover, RCC needs no forms or finishing, and there are no dowels, tie rods, or steel reinforcement. According to [39-40, 25-28] other beneficial characteristics of RCC include the following:

1. The lower paste content in RCC results in less concrete shrinkage and reduced cracking from shrinkage-related stresses.

2. RCC can be designed to have high flexural, compressive, and shear strengths, which allow it to support heavy, repetitive loads without failure - such as in heavy industrial, mining, and military applicationsand to withstand highly concentrated loads and impacts.

3. With its low permeability, RCC provides excellent durability and resistance to chemical attack, even under freeze-thaw conditions.

4. Like other rigid pavements, RCC eliminates rutting and subsequent repairs, except in areas of heavy tire chain or studded tire use.

5. For industrial applications - such as waste yards, logging facilities, and tank pads - time and costs related to joint maintenance can be eliminated because sawed joints are typically not required.

6. RCC provides chemical and rut resistance in industrial areas where point loading from trailer dollies is a concern.

7. RCC resists abrasion, similar to conventional concrete pavement, even under heavy loads and high traffic volumes.

8. Due to the light surface color of RCC pavements, lighting requirements for parking and storage areas are reduced. 


\author{
Alban Chidiebere Ogbonna \\ Effects of coarse aggregate shape and texture on engineering properties of roller compacted concrete prepared \\ for high traffic routes
}

9. Occasional light vehicles, such as cars and light trucks, can travel at low speeds on RCC pavements soon after completion without causing damage.

10.RCC mixtures can use both natural and manufactured fine aggregates.

11.Fine aggregates not suitable for asphalt pavements can be used in RCC.

12.Depending on the mix, and utilizing high-density pavers, RCC can be placed in lifts as thick as $10 \mathrm{in} .(25.4 \mathrm{~cm})$.

13.Freeze-thaw durability of RCC is high, even without the use of air entrainment. For decades, RCC pavements in cold regions in Canada and the northern United States have shown excellent freeze-thaw resistance.

RCC pavement applications vary from use as a base material to unsurfaced, diamond ground highway pavement. The type of application often dictates the level of sophistication required in the design and construction. Since its first use in the U.S. and Canada in the 1970s, RCC has been used on pavement projects in harsh and mild climates under all types of wheel loadings and has provided superior performance under heavy wheel loads and difficult operating conditions. Typically, heavy-duty pavements have been constructed with RCC in log handling yards, intermodal terminals, freight depots, and other industrial applications. However, the past 10 years has brought an increase in the use of RCC to create cost-effective pavements for many conventional highway and street applications. Because RCC is a very dry mixture, containing 75 to 85 percent aggregate, proper aggregate gradation allows the aggregate to be packed through compaction, which provides the needed density and strength of the mixture [2528, 39-40].

Because of the stiffness of RCC mixtures compared to conventional concrete, more mixing energy is required, which can reduce the capacity of the mixing plant. Using the correct mixer is vital to ensuring a uniform mixture and a consistent supply to the paver. See Section 6 for more information about production, including rates for each type of mixing plant. RCC is transported using dump trucks and is placed with an asphalt-type paver. High-density asphalt pavers are commonly used for single-lift pavements up to $125.4 \mathrm{~cm}$ thick and for multiple-lift pavements greater than $25.4 \mathrm{~cm}$ thick. Conventional asphalt pavers may be used for thicknesses less than $7 \mathrm{in} .(17.8 \mathrm{~cm})$. For more information about constructing RCC pavements, see Section 7. Many RCC applications do not require jointing. However, joints can be sawed in order to initiate crack locations, improve aesthetic appearance, or minimize crack openings for improved load transfer. See Sections 5 and 7 for information on joint design and construction. Selecting RCC for appropriate applications results in a sustainable pavement- 
one that meets the economic, environmental, and social demands of today's infrastructure [25-28].

According to [39-40, 25-28] RCC pavements represent a sustainable option because they have the following qualities:

1. Low embodied primary energy due to low production and maintenance energy use Reduced construction fuel demand compared to asphalt pavements, due to thicker lifts

2. Ability to use natural aggregates in the most cost-effective manner (by eliminating the need for substantial granular subbase) while still providing high structural load-carrying capacity

3. Ability to consume industrial byproducts such as fly ash; ground, granulated blast furnace (GGBF) slag; and silica fume • Ability to use more non-plastic fines, which reduces waste materials at quarries

4. Longevity

5. Low wheel-rolling resistance, which increases fuel economy $\bullet$ Negative texture (needed for quiet pavements)

6. Recyclability for use as future concrete or granular base

7. High heat and light reflectance to provide the most cost-effective solution that will meet the desired expectations, the unique criteria of each RCC application must be considered. The following pages outline typical factors to consider for different RCC pavement applications.

Roller Compacted Concrete Pavement (RCCP) is placed without forms, finishing, and surface texturing. RCCP does not require joints, dowels, reinforcing steel, or formwork. Therefore, relatively large quantities of RCCP can be placed rapidly with minimal labor and equipment, resulting in speedy completion of tightly scheduled pavements. Because of the low water to cementitious materials ratio in a RCCP mixture, it typically exhibits strengths equivalent to, or greater than, conventional concrete pavements $[7,8,10,25]$. .

The surface quality and smoothness of RCC pavements are relatively inferior to conventional pavements. As a result, RCCP has primarily been used in heavy duty or industrial pavements such as log-yards, port facilities, tank parking areas, warehouses, etc. where minor surface deficiencies are not an issue. More recent applications of RCCP include industrial plants, public highways, road subbases, truck lane inlays, overlays, intersection inlays, arterial roads, bridge decks, liner for evaporation/drying beds, sludge drying basins, etc [7, 8, 10, 25]. This study aims at evaluating the effects of coarse aggregate shape and texture on strength properties of roller compacted concrete pavement. 


\section{METHODOLOGY}

\subsection{Material}

\subsubsection{Hydraulic Cement}

RCC mixtures can be made with any of the basic types of hydraulic cement, blended cements, or a combination of hydraulic cement and pozzolan [22, 23,27, $28,30,31]$. The hydraulic cement used in this study conforms to the specifications of $[2,6,9,20,24]$.

As with conventional concrete, materials used in RCC mixtures should be selected for chemical resistance to sulfate attack, potential alkali reactivity, and resistance to abrasion. The type of cementitious material used has a significant effect on the rate of hydration and the rate of strength development and, therefore, significantly affects strength at early ages [26].

RCC mixtures can be made with any of the basic types of hydraulic cement, blended cements, or a combination of hydraulic cement and pozzolan. A detailed discussion of the selection and use of hydraulic cements and supplementary cementitious materials can be found in [9] ACI 225R, Guide to the Selection and Use of Hydraulic Cements, and Integrated Materials and Construction Practices for Concrete Pavement: A State-of-the-Practice Manual (IMCP 2007). As with conventional concrete, materials used in RCC mixtures should be selected for chemical resistance to sulfate attack, potential alkali reactivity, and resistance to abrasion. The type of cementitious material used has a significant effect on the rate of hydration and the rate of strength development and, therefore, significantly affects strength at early ages. Type I and II cements are commonly used in RCC pavements. Type III can be used when early strength gain is required, and Type $\mathrm{V}$ can be used in areas that have specific soil conditions calling for this type of cement. Cementitious materials should meet the requirements of ASTM C150 or ASTM C1157. Supplementary cementitious materials (SCM) can also be used to provide additional fine material and ensure adequate compaction, particularly in mixtures containing standard graded concrete fine aggregate. However, SCMs have not been extensively used in RCC mixtures in the United States. When used, SCMs may improve workability, reduce the potential for alkali aggregate reaction and alkali-silica reactivity, extend the compaction time, and - in the case of silica fume- - help in freeze-thaw conditions [9]. 


\subsubsection{Fine Aggregate}

Fine aggregates should meet the durability requirements specified in [21, 3]. The use of aggregate fractions finer than the No. $200(75 \mu \mathrm{m})$ sieve, if the fines are non-plastic, may help reduce fine aggregate voids in RCC mixtures. The selection of fine aggregates is crucial because it determines the water requirement (and hence the cement consumption), compatibility, surface smoothness, and durability of the RCC. River sand is a good source of concrete sand; however, manufactured sand is also widely accepted and used in RCC production. Screenings from crushed rock may also be used with care taken to ensure the consistency of the product $[10,11,27,28,30,31]$.

Silts and clays in RCC aggregates should be avoided because they can increase shrinkage and reduce strength. It is recommended that the plasticity index of the material passing the No. 40 sieve be reduced to four. Aggregate fines are typically in the range of 2 to 8 percent passing the No. $200(75 \mu \mathrm{m})$ sieve. The fine aggregate used in this study conforms to the specifications of [21].

\subsubsection{Coarse Aggregate of different shapes}

The cubical, irregular and angular shaped coarse aggregates used in this study conforms to the specifications of $[1,21]$. The rounded/spherical shaped coarse aggregate were natural river coarse aggregate and flaky shaped coarse aggregate were obtained from the quarry site. Coarse aggregates meeting [1,21] standards are recommended for RCC mixtures.

Coarse aggregates are often limited to nominal maximum size aggregate (NMSA) of 3/4 in. $(19 \mathrm{~mm})$ to prevent segregation and achieve a tight surface. Typical NMSA varies from 5/8 to $3 / 4$ in. (16 to $19 \mathrm{~mm}$ ). NMSAs larger than $3 / 4$ in. $(19 \mathrm{~mm}$ ) (up to $11 / 2 \mathrm{in}$. [38 mm]) can be used and, if properly proportioned (with adequate fines), can render a good quality finish. Larger NMSAs are typically used for non-wearing course or secondary applications where surface appearance is not of high importance. NMSAs smaller than 3/4 in. (19 mm) (as small as $1 / 2$ in. [13 $\mathrm{mm}]$ ) can be used to reduce segregation, enhance cohesiveness, provide a closed surface, and improve riding quality. However, a smaller NMSA can increase the cement consumption and reduce the strength potential of the pavement [26]. 


\subsection{Methods}

\subsubsection{Aggregate Properties}

Mineral aggregates constitute up to $85 \%$ of the volume of RCC and play an influential role in achieving the required workability, specified density in the field under vibratory compaction, compressive and flexural strengths, thermal properties, long-term performance, and durability. Aggregates used in conventional concrete with a good proven record should also perform well in RCC. As with conventional concrete, the aggregate source should be inspected and tested for quality and consistency throughout the construction period. Testing can be performed to confirm the consistency of the aggregate gradation as well as properties such as absorption, specific gravity, plasticity index, abrasion resistance, alkali-silica reactivity (ASR), and durability [26-28, 31, 33].

The sieve analysis was conducted for fine and coarse aggregate in accordance with [16]. The specific gravity and water absorption of the fine and coarse aggregate were conducted in accordance with $[4,5]$ respectively. The aggregate crushing value and the Los-Angeles abrasion value tests were conducted for the coarse aggregate in accordance with [4, 5, 11, 13, 16, 22, 27].

\subsubsection{Mix design and Slump test}

The correct proportioning of the materials is critical to the production of quality RCC mixtures. The mixture design process should not use a trial and-error approach, but rather a scientific and systematic approach that takes into account the desired engineering properties, construction requirements, and economics. The concrete mixes were designed and batched in accordance with the specifications of $[10,11,30,31]$. The mixing water confirms with the specifications of [14, 22-24, 27, 28, 33]. The water cement ratio was maintained at 0.4 and the maximum size of coarse aggregate used was $19 \mathrm{~mm}$. The slump test was carried out to determine the consistency of the fresh concrete and it is in conformance with $[11,12,30,31]$.

\subsubsection{Compressive strength and Flexural strength}

The compressive strength of RCC is comparable to that of conventional concrete, typically ranging from 28 to $41 \mathrm{MPa}$. Some projects have reached compressive strengths higher than $48 \mathrm{MPa}$; however, practical construction and cost considerations would likely specify increased thickness rather than strengths of this nature. The densely graded aggregates used in RCC mixtures help the 
concrete achieve high levels of compressive strength. The low w/cm of RCC mixtures produces a low-porosity cement matrix that also contributes to the high compressive strength of the concrete. Every mixture proportion has an optimum moisture content at which it achieves the maximum dry density. This density most often provides the maximum strength. Section 4 provides the mix proportioning steps to achieve the desired mix design strength [25-28, 39-40].

Flexural strength is directly related to the density and compressive strength of the concrete mixture. In properly constructed RCC pavements, the aggregates are densely packed and minimize the development of fatigue cracking. The density of the paste and the strength of its bond to the aggregate particles are high due to its low w/cm ratio. As a result, the flexural strength of RCC, depending on the mix design, is generally high ranging from 3.5 to $7 \mathrm{MPa}$. There is less information available on the flexural strength of RCC because of the difficulty of obtaining sawed beam specimens from actual paving sites and the absence of a standardized test method for fabricating beams in the field and laboratory. Based on beams and cores obtained from a test section, the relationship between the compressive and flexural strengths of RCC appears to be similar to that for conventional concrete [25-28].

The strength properties of RCC depend on the amount of cementitious materials, water/cement ratio, quality of aggregates, and degree of compaction of the concrete. In general, RCC pavements can have compressive and flexural strengths comparable to those of conventional concrete pavements. Mix design analysis is conducted as necessary to meet design strength criteria [9].

The concrete specimens were of $150 \mathrm{~mm}$ diameter and $300 \mathrm{~mm}$ long for both compressive strength and split tensile analysis. The compressive strength of the specimens was evaluated at the $3^{\text {rd }}, 7^{\text {th }}, 14^{\text {th }}, 28^{\text {th }}, 56^{\text {th }}$ and $91^{\text {st }}$ day age in accordance with the specifications of [11, 17-19, 22, 23, 27, 28, 30, 31, 33]. The flexural strength was conducted in accordance with [11, 17, 22, 23, 27, 28, 30, 31, 33]. The specimens used for the flexural strength test were Simple Beams of $700 \mathrm{~mm}$ long by $150 \mathrm{~mm}$ width and $150 \mathrm{~mm}$ depth with Third-Point Loading.

\subsection{4: Water absorption and Voids in hardened concrete:}

The density, percentage absorption, and percentage voids in hardened concrete made from coarse aggregate of different shape and texture were determined in accordance with the procedure specified in $[15,29]$ at the $28^{\text {th }}$ day and $91^{\text {st }}$ day of curing. The specimens used were $100 \mathrm{~mm}$ diameter and $50 \mathrm{~mm}$ thick cylindrical concrete of volume $393 \mathrm{~cm}^{3}$ and oven dry mass as shown in Tables 5 and 6 . Each portion of the specimens were free from observable cracks, 
fissures, or shattered edges. Equations 1-7 are used to calculate water absorption, voids and densities of hardened concrete.

Absorption after immersion $(\%)=\left[\frac{(\mathrm{B}-\mathrm{A})}{\mathrm{A}}\right] \times 100$

Absorption after immersion and boiling $(\%)=\left[\frac{(\mathrm{C}-\mathrm{A})}{\mathrm{A}}\right] \times 100$

Bulk density, dry $\left(\mathrm{g} / \mathrm{cm}^{3}\right)=\mathrm{g}_{1}=\left[\frac{\mathrm{A}}{\mathrm{C}-\mathrm{D}}\right] X \rho$

Bulk density after immersion $\left(\mathrm{g} / \mathrm{cm}^{3}\right)=\left[\frac{\mathrm{B}}{\mathrm{C}-\mathrm{D}}\right] X \rho$

Bulk density after immersion and boiling $\left(\mathrm{g} / \mathrm{cm}^{3}\right)=\left[\frac{\mathrm{C}}{\mathrm{C}-\mathrm{D}}\right] X \rho$

Apparent density $\left(\mathrm{g} / \mathrm{cm}^{3}\right)=\mathrm{g} 2=\left[\frac{\mathrm{A}}{\mathrm{A}-\mathrm{D}}\right] X \rho$

Volume of permeable pore space or voids, $(\%)=\left[\frac{\mathrm{g} 2-\mathrm{g} 1}{\mathrm{~g} 2}\right] X 100$ or $\left[\frac{(\mathrm{C}-\mathrm{A})}{(\mathrm{C}-\mathrm{D})}\right] \times 100$

Where,

Volume of concrete sample $\left(\mathrm{cm}^{3}\right)=\mathrm{V}$

Mass of oven dry sample in air $(\mathrm{g})=\mathrm{A}$

Mass of surface-dry sample in air after immersion $(\mathrm{g})=\mathrm{B}$

Mass of surface-dry sample in air after immersion and boiling $(\mathrm{g})=\mathrm{C}$

Apparent mass of sample in water after immersion and boiling $(\mathrm{g})=\mathrm{D}$

Density of water $\left(\mathrm{g} / \mathrm{cm}^{3}\right)=\rho=1$

\section{RESULTS AND DISCUSSION}

\subsection{Aggregate Properties}

Roller Compacted Concrete (RCC) differs from conventional concrete in its gradation requirements. The different gradation requirement comes from the need of the RCC aggregate skeleton to be consolidated under compaction efforts from the paver and the steel drum and rubber-tired rollers. The fine and coarse aggregate gradation should be selected to ensure workability, compatibility, and surface finish. Selection of proper aggregates and aggregate gradation for RCC pavements reduces the potential for segregation and improves the strength and durability of the pavement. Aggregate selection will also affect both the water requirements and the amount of cementitious materials needed. Practices for selecting and blending aggregates may vary depending on the local practices, construction specifications, severity of exposure, and availability of different sizes, as well as the convenience of the concrete producer and contractor and the economic environment. Crushed or uncrushed aggregates or blends may be used in RCC mixtures, depending primarily on availability. A dense, well-graded aggregate blend is most desirable [11, 22, 27]. 
The shape of coarse aggregates is important; flaky particles and excessively elongated particles should be avoided, with an objective of providing economical, strong, and long-lasting concrete. The fine aggregate used has specific gravity of 2.61 and water absorption of 1.98. From Table 1, it can be observed that the properties of the coarse aggregates used in this study satisfied the specifications of $[1,11,22,27]$.

Table 1: Properties of the coarse aggregate used

\begin{tabular}{cccccc}
\hline $\begin{array}{c}\text { Coarse aggregate } \\
\text { shape and texture }\end{array}$ & $\begin{array}{c}\text { Specific } \\
\text { gravity }\end{array}$ & $\begin{array}{c}\text { Water } \\
\text { absorption } \\
(\%)\end{array}$ & $\begin{array}{c}\text { Aggregate } \\
\text { crushing } \\
\text { value }(\%)\end{array}$ & $\begin{array}{c}\text { Aggregate } \\
\text { impact value } \\
(\%)\end{array}$ & $\begin{array}{c}\text { Los Angeles } \\
\text { abrasion value } \\
(\%)\end{array}$ \\
\hline Cubical and rough & 2.731 & 1.23 & 17.00 & 18.74 & 21.32 \\
Irregular and rough & 2.731 & 1.23 & 19.63 & 22.54 & 24.71 \\
Angular and rough & 2.731 & 1.23 & 21.18 & 23.20 & 25.61 \\
$\begin{array}{c}\text { Rounded/Spherical } \\
\text { and smooth }\end{array}$ & 1.682 & 1.55 & 28.11 & 33.22 & 37.00 \\
$\begin{array}{c}\text { Flaky/Elongated and } \\
\text { rough }\end{array}$ & 2.731 & 1.23 & 35.87 & 39.21 & 43.65 \\
\hline
\end{tabular}

\subsection{Concrete Mix proportioning}

Roller Compacted Concrete (RCC) should be designed using well-graded aggregates to optimize paste content, minimize void space, reduce segregation, and provide a dense, smooth, tight surface. RCC mixtures often require a higher proportion of fine aggregate to coarse aggregate than conventional concrete [10, $22,23,27,28,30,31,33]$. RCC aggregates should meet the quality requirements of [21] or other agency-approved sources. From Table 2, it can be observed that hydraulic cement content is $343 \mathrm{Kg} / \mathrm{m}^{3}$, the fine aggregate to total aggregate ratio is 0.5 and the coarse aggregate to total aggregate ratio is 0.5 . This satisfies the minimum cementitious content of $300 \mathrm{Kg} / \mathrm{m}^{3}$ to $360 \mathrm{Kg} / \mathrm{m}^{3}$ for concrete pavement, the fine aggregate to total aggregate ratio specifications of 0.50 to 0.55 and the coarse aggregate to total aggregate ratio of 0.45 to 0.5 for roller compacted concrete pavement specified in [10, 22, 23, 27, 28, 30, 31, 33].

The water - content ratio shown in Table 2 , satisfied the specifications of $[10,22,27,28,31,33]$ and it is such that the mixture is dry enough to support the weight of a vibratory roller (no-slump mixture) yet wet enough to ensure an even distribution of the cement paste. The water quality satisfied the specifications of [14]. 
ROMANIAN JOURNAL

OF TRANSPORT INFRASTRUCTURE

Alban Chidiebere Ogbonna

Effects of coarse aggregate shape and texture on engineering properties of roller compacted concrete prepared for high traffic routes

Table 2: Concrete Mix proportioning of 1:3:3

\begin{tabular}{ccccccc}
\hline $\begin{array}{c}\text { Concrete } \\
\text { cylindrical } \\
\text { specimen } \\
\text { mark }\end{array}$ & $\begin{array}{c}\text { Coarse aggregate } \\
\text { content }\end{array}$ & $\begin{array}{c}\text { Water } \\
\text { cement } \\
\text { ratio }\end{array}$ & $\begin{array}{c}\text { Mixing } \\
\text { water } \\
\left(\mathrm{Kg} / \mathrm{m}^{3}\right)\end{array}$ & $\begin{array}{c}\text { Cement } \\
\left(\mathrm{Kg} / \mathrm{m}^{3}\right)\end{array}$ & $\begin{array}{c}\text { Fine } \\
\text { aggregate } \\
\left(\mathrm{Kg} / \mathrm{m}^{3}\right)\end{array}$ & $\begin{array}{c}\text { Coarse } \\
\text { aggregate } \\
\left(\mathrm{Kg} / \mathrm{m}^{3}\right)\end{array}$ \\
\hline CA1 & $\begin{array}{c}\text { Cubical and rough } \\
\text { CA2 }\end{array}$ & 0.4 & 137 & 343 & 1029 & 1029 \\
Irregular and rough & 0.4 & 137 & 343 & 1029 & 1029 \\
CA4 & $\begin{array}{c}\text { Angular and rough } \\
\text { Rounded/Spherical } \\
\text { and smooth }\end{array}$ & 0.4 & 137 & 343 & 1029 & 1029 \\
CA5 & $\begin{array}{c}\text { Flaky/Elongated and } \\
\text { rough }\end{array}$ & 0.4 & 137 & 343 & 1029 & 1029 \\
\hline
\end{tabular}

\subsection{Compressive strength and Flexural strength of Roller Compacted Concrete.}

Tables 3 and 4 show the compressive strength and flexural strength tests results. From Table 3 and Figures 1 and 2 it can be observed that concrete specimens made with cubical and rough coarse aggregate, irregular and rough coarse aggregate, and angular and rough coarse aggregate satisfied the[10, 22, 23, $27,28,30,31,33$ ] minimum 28 days compressive strength of $31 \mathrm{~N} / \mathrm{mm}^{2}$ to $41 \mathrm{~N} / \mathrm{mm}^{2}$ for standard roller compacted concrete pavement and the minimum 28 days compressive strength of $35 \mathrm{~N} / \mathrm{mm}^{2}$ to $41 \mathrm{~N} / \mathrm{mm}^{2}$ for high performance and high strength roller compacted concrete pavement respectively. The compressive strength for all the concrete specimens increases with increase in curing age with the Flaky/Elongated and rough coarse aggregate having the least 28 days compressive strength.

According to [6] no-slump concrete is freshly mixed concrete exhibiting a slump of less than $1 / 4$ inch $(6.25 \mathrm{~mm})$. Zero-slump concrete is defined in the same document, as concrete of stiff or extremely dry consistency showing no measurable slump after removal of the slump cone.

The slump values shown in Table 3 are within the range of $0.00 \mathrm{~mm}$ to $6.00 \mathrm{~mm}$ for concretes made with that cubical and rough coarse aggregate, irregular and rough coarse aggregate, and angular and rough coarse aggregate. This satisfied the $[10,22,23,27,28,30,31,33]$ definition of $0.00 \mathrm{~mm}$ to $6.25 \mathrm{~mm}$ for zero slump concrete which roller compacted concrete belongs to. The flexural strength results for all concrete specimens shown in Table 4 satisfied the minimum 28 days flexural strength of $3.5 \mathrm{~N} / \mathrm{mm}^{2}$ to $7.00 \mathrm{~N} / \mathrm{mm}^{2}$. 
ROMANIAN JOURNAL

OF TRANSPORT INFRASTRUCTURE

Alban Chidiebere Ogbonna

Effects of coarse aggregate shape and texture on engineering properties of roller compacted concrete prepared for high traffic routes

Table 3: Slump and compressive strength of Roller compacted concrete (RCC)

\begin{tabular}{|c|c|c|c|c|c|c|c|c|}
\hline \multirow{2}{*}{$\begin{array}{l}\text { Concrete } \\
\text { mark }\end{array}$} & \multirow{2}{*}{$\begin{array}{c}\text { Coarse aggregate } \\
\text { content }\end{array}$} & \multirow{2}{*}{$\begin{array}{l}\text { Slump } \\
(\mathrm{mm})\end{array}$} & \multicolumn{5}{|c|}{ Compressive strength $\left(\mathrm{N} / \mathrm{mm}^{2}\right)$} & \multirow[b]{2}{*}{$\begin{array}{c}91 \\
\text { days }\end{array}$} \\
\hline & & & 3 days & 7 days & $\begin{array}{c}14 \\
\text { days }\end{array}$ & 28 days & $\begin{array}{c}56 \\
\text { days }\end{array}$ & \\
\hline CA1 & Cubical and rough & 3.0 & 17.52 & 24.37 & 32.11 & 41.67 & 48.46 & 57.29 \\
\hline CA2 & Irregular and rough & 3.0 & 16.34 & 23.44 & 31.53 & 40.13 & 46.76 & 54.87 \\
\hline CA3 & Angular and rough & 3.0 & 13.46 & 19.27 & 28.66 & 36.01 & 41.04 & 48.43 \\
\hline CA4 & $\begin{array}{l}\text { Rounded/Spherical } \\
\text { and smooth }\end{array}$ & 4.0 & 10.11 & 15.67 & 24.43 & 30.45 & 35.12 & 41.24 \\
\hline CA5 & $\begin{array}{c}\text { Flaky/Elongated and } \\
\text { rough }\end{array}$ & 5.0 & 7.31 & 12.16 & 19.23 & 25.46 & 30.45 & 36.24 \\
\hline
\end{tabular}

Table 4. Flexural strength of Roller compacted concrete (RCC)

\begin{tabular}{ccc|c}
\hline Concrete mark & Coarse aggregate content & \multicolumn{2}{c}{ Flexural strength $\left(\mathrm{N} / \mathrm{mm}^{2}\right)$} \\
\cline { 3 - 4 } & & 7 days & 28 days \\
\hline CA1 & Cubical and rough & 4.44 & 6.11 \\
CA2 & Irregular and rough & 4.01 & 5.03 \\
CA3 & Angular and rough & 4.01 & 5.03 \\
CA4 & Rounded/Spherical and smooth & 3.45 & 4.11 \\
CA5 & Flaky/Elongated and rough & 2.33 & 3.51 \\
\hline
\end{tabular}

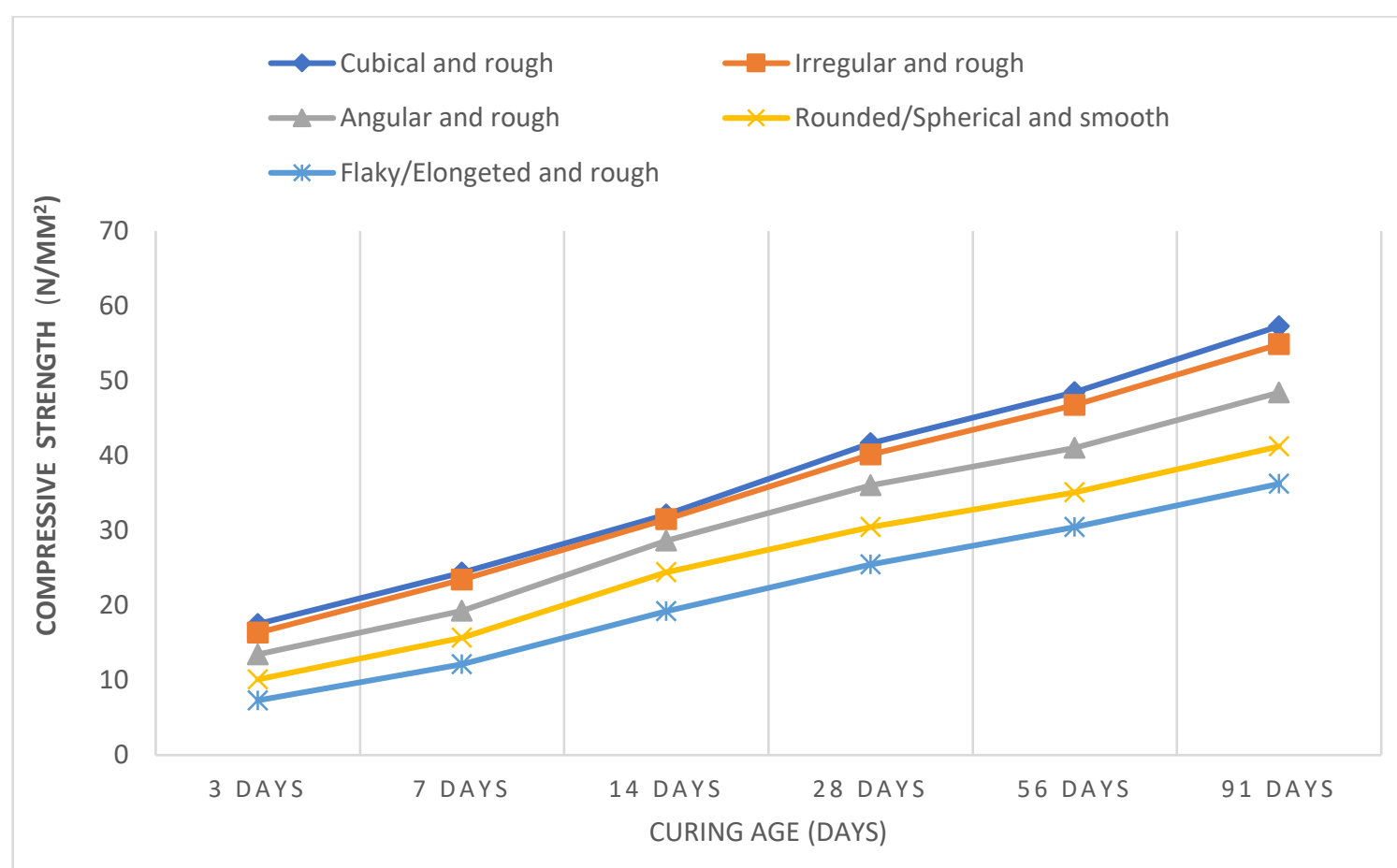

Figure 1. Relationship between compressive strength (N/mm $\left.{ }^{2}\right)$ and Curing age (days) 
ROMANIAN JOURNAL

OF TRANSPORT INFRASTRUCTURE

Alban Chidiebere Ogbonna

Effects of coarse aggregate shape and texture on engineering properties of roller compacted concrete prepared for high traffic routes

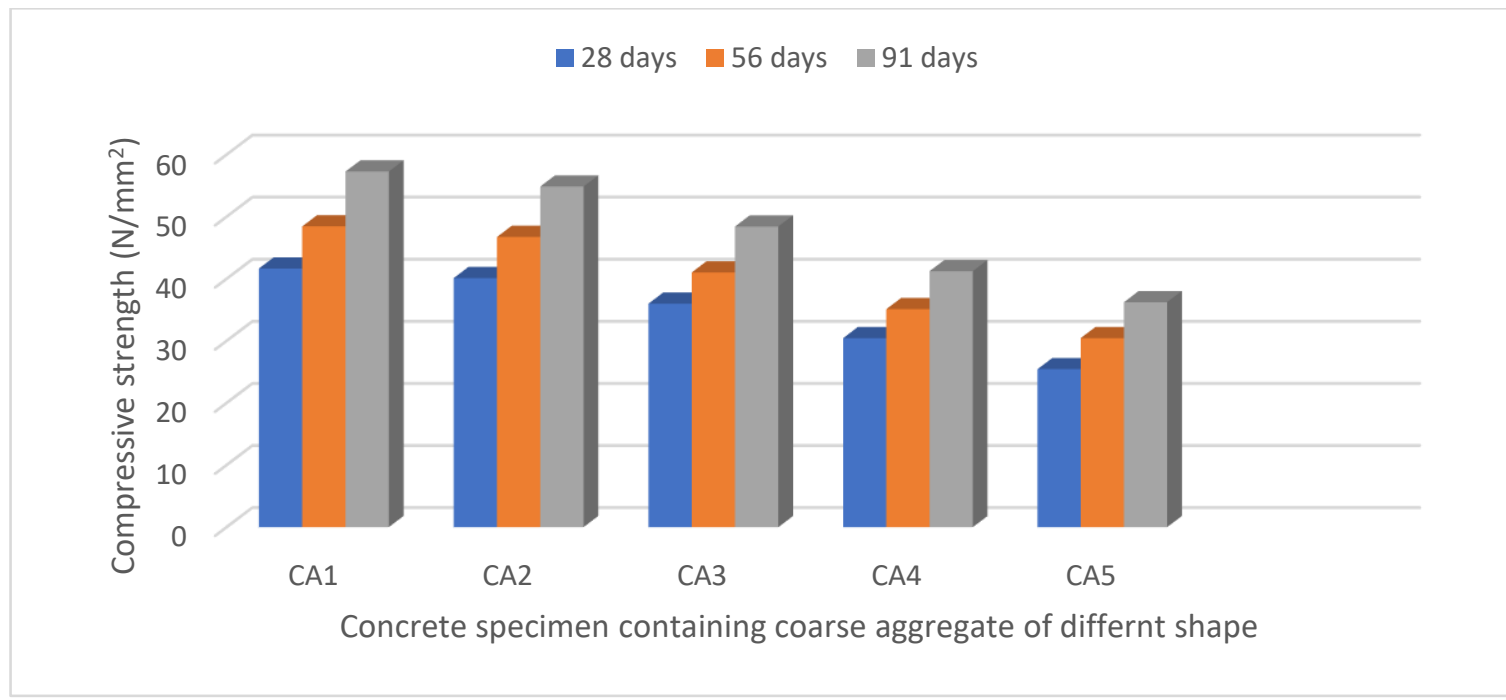

Figure 2. The 28 days and 56 days compressive strength of concrete specimens containing coarse aggregate of different shape and texture.

\section{4: Water absorption and Voids in hardened concrete:}

The specimen used for the Water absorption and Volume of permeable pore space (voids) in hardened concrete at $28^{\text {th }}$ and $91^{\text {st }}$ day curing age satisfied the specifications of $[15,29]$. From Tables 5 and 6 and Figure 3 it can be observed that water absorption after immersion, water absorption after immersion and boiling and volume of permeable pore space (voids) decrease with age. The concrete made with cubical, irregular and angular shaped coarse aggregate have low water absorption and low volume of permeable pore spaces (voids). This indicates reliable durability qualities. Permeability of the concrete in a Portland cement concrete pavement is a major factor for long-term durability. Pavements with low permeability resist penetration of moisture into the concrete matrix, leading to long-term durability. 


\section{ROMANIAN JOURNAL \\ OF TRANSPORT INFRASTRUCTURE}

Alban Chidiebere Ogbonna

Effects of coarse aggregate shape and texture on engineering properties of roller compacted concrete prepared for high traffic routes

Table 5: Water absorption and Volume of permeable pore space (voids) in hardened concrete at $28^{\text {th }}$ day.

\begin{tabular}{|c|c|c|c|c|c|c|}
\hline \multirow[t]{2}{*}{$\mathbf{S} / \mathbf{N}$} & \multirow[t]{2}{*}{ Description and units } & \multicolumn{5}{|c|}{$\begin{array}{l}\text { Concrete specimens containing coarse } \\
\text { aggregate of different shape and texture. }\end{array}$} \\
\hline & & CA1 & CA2 & CA3 & CA4 & CA5 \\
\hline 1. & Volume of sample $\left(\mathrm{cm}^{3}\right)$ & 393 & 393 & 393 & 393 & 393 \\
\hline 2. & Mass of oven dry sample in air (g) & 972 & 960 & 952 & 943 & 943 \\
\hline 3. & Mass of surface-dry sample in air after immersion (g) & 990 & 985 & 976 & 987 & 998 \\
\hline 4. & $\begin{array}{c}\text { Mass of surface-dry sample in air after immersion and } \\
\text { boiling }(\mathrm{g})\end{array}$ & 994 & 990 & 984 & 994 & 1007 \\
\hline 5. & $\begin{array}{c}\text { Apparent mass of sample in water after immersion and } \\
\text { boiling }(\mathrm{g})\end{array}$ & 601 & 597 & 591 & 601 & 614 \\
\hline 6. & Absorption after immersion $(\%)$ & 1.82 & 2.55 & 2.54 & 4.65 & 5.86 \\
\hline 7. & Absorption after immersion and boiling (\%) & 2.23 & 3.15 & 3.32 & 5.35 & 6.79 \\
\hline 8. & Density of water $\left(\mathrm{g} / \mathrm{cm}^{3}\right)$ & - & - & - & - & - \\
\hline 9. & Bulk density, dry $\left(\mathrm{g} / \mathrm{cm}^{3}\right)$ & 2.47 & 2.44 & 2.42 & 2.40 & 2.40 \\
\hline 10. & Bulk density after immersion $\left(\mathrm{g} / \mathrm{cm}^{3}\right)$ & 2.52 & 2.51 & 2.49 & 2.51 & 2.54 \\
\hline 11. & Bulk density after immersion and boiling $\left(\mathrm{g} / \mathrm{cm}^{3}\right)$ & 2.53 & 2.52 & 2.50 & 2.53 & 2.56 \\
\hline 12. & Apparent density $\left(\mathrm{g} / \mathrm{cm}^{3}\right)$ & 2.62 & 2.65 & 2.64 & 2.76 & 2.87 \\
\hline 13. & Volume of permeable pore space or voids, $(\%)$ & 5.73 & 7.93 & 8.33 & 13.04 & 16.38 \\
\hline
\end{tabular}

Table 6: Water absorption and Volume of permeable pore space (voids) in hardened concrete at $91^{\text {st }}$ day.

\begin{tabular}{|c|c|c|c|c|c|c|}
\hline \multirow[t]{2}{*}{$\mathbf{S} / \mathbf{N}$} & \multirow[t]{2}{*}{ Description and units } & \multicolumn{5}{|c|}{$\begin{array}{l}\text { Concrete specimens containing coarse } \\
\text { aggregate of different shape and texture. }\end{array}$} \\
\hline & & CA1 & CA2 & CA3 & CA4 & CA5 \\
\hline 1. & Volume of sample $\left(\mathrm{cm}^{3}\right)$ & 393 & 393 & 393 & 393 & 393 \\
\hline 2. & Mass of oven dry sample in air (g) & 972 & 960 & 952 & 943 & 943 \\
\hline 3. & Mass of surface-dry sample in air after immersion (g) & 980 & 974 & 971 & 976 & 989 \\
\hline 4. & $\begin{array}{c}\text { Mass of surface-dry sample in air after immersion and } \\
\text { boiling (g) }\end{array}$ & 983 & 982 & 980 & 981 & 998 \\
\hline 5. & $\begin{array}{c}\text { Apparent mass of sample in water after immersion and } \\
\text { boiling }(\mathrm{g})\end{array}$ & 590 & 589 & 587 & 588 & 605 \\
\hline 6. & Absorption after immersion (\%) & 0.82 & 1.45 & 2.04 & 3.47 & 4.91 \\
\hline 7. & Absorption after immersion and boiling (\%) & 1.11 & 2.31 & 2.97 & 4.05 & 5.82 \\
\hline 8. & Density of water $\left(\mathrm{g} / \mathrm{cm}^{3}\right)$ & - & - & - & - & - \\
\hline 9. & Bulk density, dry $\left(\mathrm{g} / \mathrm{cm}^{3}\right)$ & 2.47 & 2.44 & 2.42 & 2.40 & 2.40 \\
\hline 10. & Bulk density after immersion $\left(\mathrm{g} / \mathrm{cm}^{3}\right)$ & 2.50 & 2.48 & 2.47 & 2.48 & 2.52 \\
\hline 11. & Bulk density after immersion and boiling $\left(\mathrm{g} / \mathrm{cm}^{3}\right)$ & 2.50 & 2.50 & 2.49 & 2.50 & 2.54 \\
\hline 12. & Apparent density $\left(\mathrm{g} / \mathrm{cm}^{3}\right)$ & 2.55 & 2.59 & 2.61 & 2.66 & 2.79 \\
\hline 13. & Volume of permeable pore space or voids, $(\%)$ & 3.1 & 5.8 & 7.30 & 9.80 & 14.00 \\
\hline
\end{tabular}


ROMANIAN JOURNAL

OF TRANSPORT INFRASTRUCTURE

Alban Chidiebere Ogbonna

Effects of coarse aggregate shape and texture on engineering properties of roller compacted concrete prepared for high traffic routes

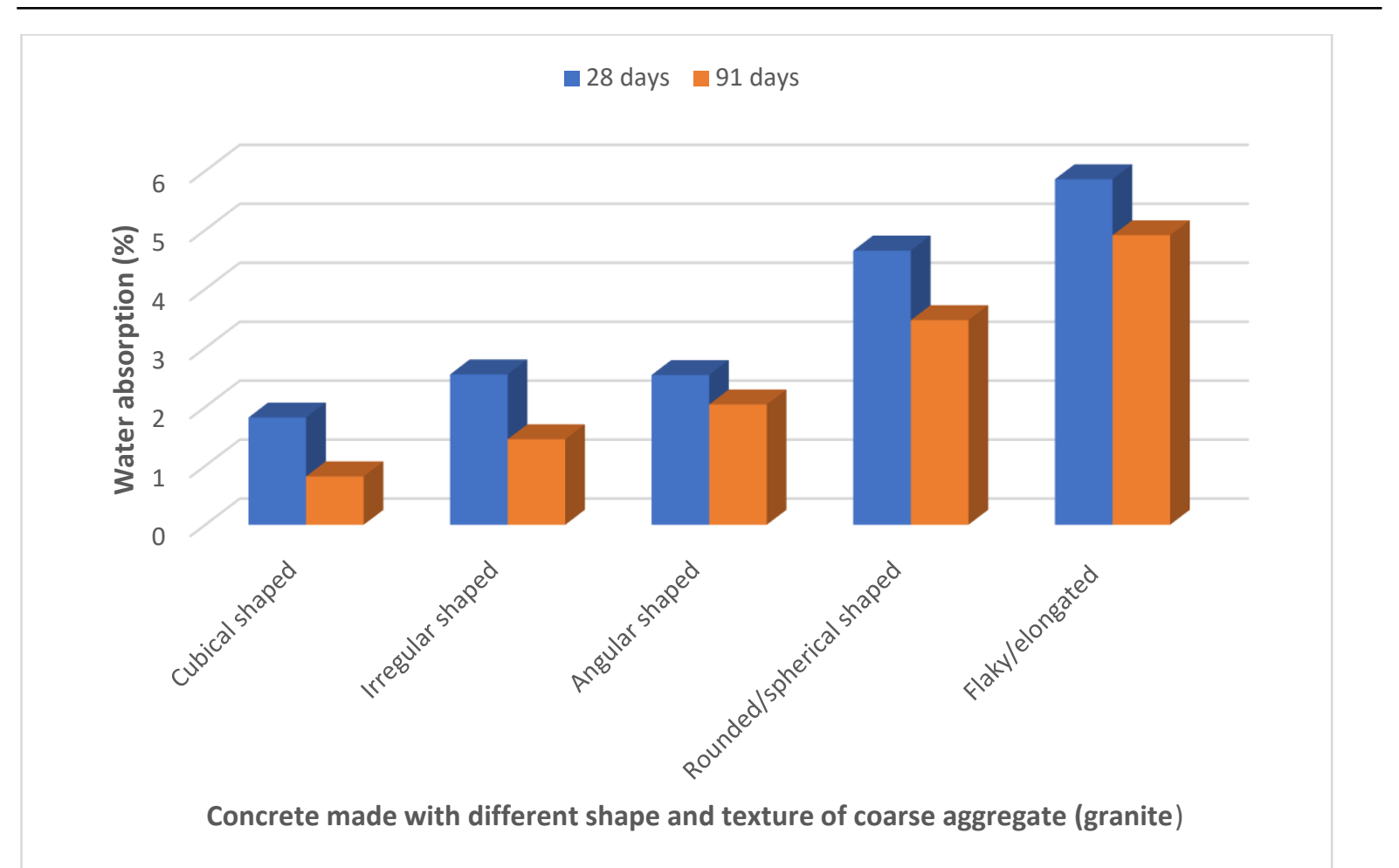

Figure 3: Water absorption after immersion in hardened concrete at $\mathbf{2 8}^{\text {th }}$ and $91^{\text {st }}$ days curing age $(\%)$

\section{CONCLUSION}

At the end of this study, the following conclusions can be drawn:

(a). The shape and texture of coarse aggregate affect the properties of fresh and hardened concrete. Aggregates shape and size has a strong influence on properties of concrete. Rough surface textured coarse aggregates increase the compressive strength of roller compacted concrete pavement, instead of using natural gravels that is obtained from riverbeds. Rough surfaces have pores which have ability to form bond or create resistance against the applied load.

b. Rounded/Spherical and smooth coarse aggregate and Rounded/Spherical and smooth coarse aggregate should not be used in construction and maintenance of roller compacted concrete pavement.

(c). Well graded cubical and rough coarse aggregate, irregular and rough coarse aggregate, and angular and rough coarse aggregate should be used in the construction and maintenance of roller compacted concrete pavement since concrete made with them satisfied the [10, 22, 23, 27, 30,31, 33] specifications for coarse aggregate and concrete specimens prepared using coarse aggregate of 
their shape and texture satisfied the 28 days minimum compressive strength for roller compacted Concrete pavement.

\section{REFERENCES}

[1] AASHTO M80-87 (2013). Standard specification for coarse aggregate for hydraulic cement. American association of state highway officials, Washington D.C. http://www.transfortation.org/M80

[2] AASHTO M85 (2016). Standard specifications for Portland cement, American association of state highway and transportation officials. Washington D.C. http://www.transportation.org/M85

[3] AASHTO M6-03 (2013). Standard specification for fine aggregate for hydraulic cement concrete, American association of state highway and transportation officials, Washington D.C http://www.transportation.org/M6

[4] AASHTO T85 (2013). Standard method of test for specific gravity and absorption of coarse aggregate. American association of state highway and transportation officials. Washington D.C. http://www.transportation.org

[5] AASHTO T-84 (2013). Standard method of test for specific gravity and absorption of fine aggregate. American association of state highway and transportation officials, Washington D.C. http://www.transportation.org

[6] ACI 116R-00 (2005).Cement and Concrete Terminology. American Concrete Institute, Farmington Hills, MI, USA. https://www.concrete.org/116R-00

[7] ACI 330, (2008). "Guide for the Design and Construction of Concrete Parking Lots," ACI Report 330R- 08. American Concrete Institute, Farmington Hills, MI, USA. https://www.concrete.org/330

[8] ACI 325, (2002). "Guide for Design of Jointed Concrete Pavements for Streets and Local Roads," ACI Report 325.12R-02, American Concrete Institute, Farmington Hills, MI, USA. https://www.concrete.org/325

[9] ACI 225R, (2016). Guide to the Selection and Use of Hydraulic Cements, American Concrete Institute, Farmington Hills, MI, USA. https://www.concrete.org/225R ISBN: 9781945487163 
[10] ACI 325, (2004). "State-of-the-Art Report on Roller-Compacted Concrete Pavements," ACI Report 325.10R-95, American Concrete Institute, Farmington Hills, MI, USA. https://www.concrete.org/325

[11] ADOT (2008). Standard specifications for road and bridge construction. Arizona department of transportation, USA. https://www.azdot.gov/standards

[12] ASTM C143 / C143M-15a, (2015). Standard Test Method for Slump of HydraulicCement Concrete, ASTM International, West Conshohocken, PA, https://www.astm.org/C143, DOI: 10.1520/C0143_C0143M-15A

[13] ASTM C131 / C131M-14, (2006). Standard Test Method for Resistance to Degradation of Small-Size Coarse Aggregate by Abrasion and Impact in the Los Angeles Machine, ASTM International, West Conshohocken, PA, https://www.astm.org/C131, DOI: 10.1520/C0131_C0131M-14.

[14] ASTM C1602 / C1602M-12, (2012). Standard Specification for Mixing Water Used in the Production of Hydraulic Cement Concrete, ASTM International, West Conshohocken, PA, https://www.astm.org/C1602, DOI: 10.1520/C1602_C1602M12.

[15] ASTM C642 (2013). Standard Test Method for Density, Absorption, and Voids in Hardened Concrete. ASTM international, West Conshohocken, PA, www.astm.org/C642-13.

[16] ASTM C136 / C136M-14, (2014). Standard Test Method for Sieve Analysis of Fine and Coarse Aggregates, ASTM International, West Conshohocken, PA, https://www.astm.org/C136, DOI: 10.1520/C0136_C0136M-14

[17] ASTM C78 / C78M-16, (2016). Standard Test Method for Flexural Strength of Concrete (Using Simple Beam with Third-Point Loading), ASTM International, West Conshohocken, PA， https://www.astm.org/C78, DOI: 10.1520/C0078_C0078M-16.

[18] ASTM C39 / C39M-17a, (2017). Standard Test Method for Compressive Strength of Cylindrical Concrete Specimens, ASTM International, West Conshohocken, PA, https://www.astm.org/C39,DOI: 10.1520/C0039_C0039M-17A.

[19] ASTM C1435 / C1435M-14, (2014). Standard Practice for Molding Roller-Compacted Concrete in Cylinder Molds Using a Vibrating Hammer, ASTM International, West Conshohocken, PA, https://www.astm.org/C1435, DOI: 10.1520/C1435_C1435M-14. 


\section{ROMANIAN JOURNAL}

OF TRANSPORT INFRASTRUCTURE

Alban Chidiebere Ogbonna

Effects of coarse aggregate shape and texture on engineering properties of roller compacted concrete prepared for high traffic routes

[20] ASTM C150 / C150M-17, (2017). Standard Specification for Portland cement, ASTM International, West Conshohocken, PA. https://www.astm.org/C150

[21] ASTM C33 /C33M - 16e1 (2016). Standard specification for concrete aggregates, ASTM international, west Conshohocken, P.A. http://www.astm.org/C33DOI; 10.1520/C00333- C0033M-16E01

[22] CDOT (2011). Standard specifications for road and bridge construction. Colorado department of transportation Colorado. http:// www.codot.gov/standard.

[23] FDOT (2010). Standard specifications for road and bridge construction. Florida department of transportation,Tallahassee,Florida. http://http://www.fdot.gov/construction

[24] FHWA HIF - 07 - 004 (2007). Integrated Materials and Construction Practices for Concrete Pavement: A State-of-the-Practice Manual, Federal Highway Administration, United States Department of Transportation, Office of Pavement Technology, Washington D.C, USA. https://www.fhwa.dot.gov/pavement/07-004

[25] FHWA-HIF-16-003 (2016). Roller compacted concrete pavement, Tech brief, Federal highway administration, United States department of transportation, Washington DC, USA. https://www.fhwa.dot.gov/pavement

[26] Harrington, D, Abdo, F., Adaska, W., and Hazaree, C., (2010). Guide for Roller Compacted Concrete Pavements. National Concrete Pavement Technology Center, Institute for Transportation, Iowa State University, Ames, IA, USA.

[27] INDOT (2014). Standard specifications, department of transportation. Indiana department of transportation. The State of Indiana, USA. http://www.in.gov.dot

[28] NCDOT (2012). Standard specifications for roads and structures, North Carolina department of transportation, Raleigh, North Carolina, USA. http://www.ncdot.gov/standards

[29] NCPTC (2008). Concrete property test, Permeability 4-2: Permeable voids (boil test). National Concrete Pavement Teachnology Centre.http://www.cptechcenter.org.

[30] ODOT (2013). Construction and material specifications, department of transportation Columbus, Ohio. State of Ohio, USA.http://www.dot.state.oh.us 


\section{ROMANIAN JOURNAL}

OF TRANSPORT INFRASTRUCTURE

Alban Chidiebere Ogbonna

Effects of coarse aggregate shape and texture on engineering properties of roller compacted concrete prepared for high traffic routes

[31] Oregon DOT (2015). Oregon standard specifications for construction. Oregon department of transportation, Salem, Oregon, state of Oregon, USA. http://www.oregon.gov.odot

[32] Shetty M. S. (2013). "Concrete Technology: Theory and Practice" $6^{\text {th }}$ Edition, S. Chand Publishers, India.

[33] TDOT (2015). Standard specifications for road and bridge construction. Tennessee department of transportation, The State of Tennessee, USA. http://www.tn.gov/specifications

[34] Brouwers H.J.H. and Radix H.J. (2005). Self- Compacting concrete: theoretical and experimental study, Cement and Concrete research, Vol.35, Pp. 2116 -2136.

[35] Shakir A. A (2009). Data Base for Self-Compacting Concrete in Iraq, Engineering \& Technology Journal, Vol. 27, No.6.

[36] Okamura H. and Quchi M. (2003). Self Compacting Concrete, Journal of advanced concrete technology, Vol.31, Pp.5-15.

[37] Nan S and Buquan M. (2003). A new method for the mix design for the mix design of medium strength flowing concrete with low cement content, Cement and concrete composites, Vol. 25, Pp. 215-222.

[38] Sivarama S. B. and Manohar S. (2010). Influence of Aggregate size and grading in Self-Compacting Concrete mixes, proceeding of ICI-ACECON, Proceedings of the $3^{\text {rd }}$ asian conference on Estasy in concrete, IIT Madras, Chennai, India.

[39] Portland Cement Association (2010). Roller-Compacted Concrete.

[40] U.S. Army Corps of Engineers (2006). Engineering and Design Manual, RollerCompacted Concrete. http://www.usace.army.mil/inet/usace-docs/ 